\title{
The familial state: Elite family practices and state-making in the early modern Netherlands
}

\author{
JULIA ADAMS \\ University of Michigan
}

In early modern Europe, as every schoolchild learns, states and elite families were often closely interlocked. Yet family history and state theory are generally studied separately today. I try here to unite them by underlining the central role of family lineages and gender identities in the formation of patrimonial political structures, focussing on the Netherlands, a precocious and influential developer along a number of social and cultural dimensions. ${ }^{1}$ My thinking about this problem has been guided by several general questions. When did elite families and lineages anchor political stability, or contribute to political change? How did gender arrangements complement or crosscut these familial patterns? What are the implications for theories of state formation?

In the Netherlands, I argue, elite male family heads seized hold of local state offices, constituting themselves as a regent patriciate. ${ }^{2}$ Over time, increasing familial exclusiveness and the changing class character of the regents interacted with the axial position of the Dutch in the emergent world economy. The regents' dynastic grip contributed to the rise of the Netherlands as long as a locally-centered patrimonial state was an effective form of rule. But when competitor states took the first steps beyond patrimonialism toward a rational-legal bureaucratic apparatus staffed by means of patronage, the persistence of the Dutch familial state undermined the politico-economic viability of the Netherlands in the world economy. Thus, I argue that elite family patterns and dynamics in the Netherlands were one cause of that country's spectacular rise and decline.

In all patrimonial states, state officials had two concerns: securing the state that provided their office, and maintaining the status and wealth of their families and lineages. During some periods, these goals could be jointly achieved - at others, not. In the latter case, efforts by office 
holders to secure their families' position could dominate, leading officials to act in ways that promoted the decay of the state and the political economy more broadly. Variations in familial state configurations are important, of course: the Dutch state, which conjoined intense localism and patrilineal inheritance of privilege and office, differs from the pre-revolutionary French or Chinese states, to name just two examples. Nevertheless, variants of the general familial patterns and dynamics apply to all patrimonial states, as I show below. First, however, I turn to analyzing the links between patrimonial rule and elite families.

\section{Patrimonial elites, patriarchy, and privilege}

What, precisely, is patrimonialism $?^{3}$ This distinctive form of rule is typified by a segmentation of sovereignty between rulers and corporate elites. Patrimonial rulers rule by granting exclusive politico-economic rights and immunities to self-governing corporate groups, which are liable for certain reciprocal obligations to the ruler. In doing so, rulers are simultaneously gathering funds and deploying their power, while corporate elites in turn get economic concessions, political representation, and derived symbolic status. ${ }^{4}$ Sovereignty is institutionalized in a set of interdependent relationships among rulers and the corporate bodies (clans, estates, towns, guilds, chartered companies, and so forth) that undergird their rule. It is dual, not unitary, with pronounced tendencies toward further segmentation and fragmentation.

In the Netherlands, a powerful urban regent patriciate, based in corporate bodies such as the town councils (vroedschappen) and provincial states, and privileged monopolies like the East and West Indies Companies, faced a series of weak patrimonial rulers - first the Habsburgs' delegates, followed by emissaries of France and England, and finally the indigenous provincial stadholders (stadhouders), traditionally drawn from the House of Orange. ${ }^{5}$ The regents resisted their wouldbe sovereigns' efforts to govern, opposing efforts to create new corporations or revive traditional or fictive ones, to appoint relatively autonomous bureaucrats, or to call on alliances with other patrimonial powers. ${ }^{6}$ Such policies, however traditionally acceptable, threatened to disperse and devalue elite privilege, or even to abolish it altogether. But the Dutch regents could not simply dispense with their opposite numbers, the stadholders. Even in the two so-called stadholderless Eras of True Freedom (Ware Vrijheid) when the regents temporarily governed alone, their own politico-economic position drew on the executive 
capacities and symbolic incarnation of sovereign unity embodied in the institution of the stadholderate. ${ }^{7}$ The regents did gain an extraordinary degree of power within those limits. As opposed to pre-revolutionary France, where a series of rulers asserted politico-economic authority over elites in an absolutist fashion, or England, where a fractious balance was struck, Dutch corporate elites managed to gain wide control over local state offices and privileges, resulting in a locally-based estatist patrimonialism. ${ }^{8}$

Corporate elites everywhere depended on patrimonial offices and privileges, and they pursued them assiduously throughout early modern Europe - a practice known as kuiperij (machinations) or ambtsbejag (hunt for office) in the Netherlands. ${ }^{9}$ Contemporaries wrote stilted poetry hailing office and the prerogatives of privilege as a source of political power and a badge of status. "Happy Hasselaars!" enthused a typical ode on the occasion of a marriage in the Dutch regency, in this case between the cousins Gerhard Hasselaar and Suzanne Hasselaar in Amsterdam in 1752. "The country has placed in your tutelary hands/ The sword of Themis and the Depot of the Laws...." The poet further abjured Gerhard to exercise his offices in the illustrious tradition of his patrician ancestors. ${ }^{10}$ Contemporaries also thought of money. "Everyone knows that the quickest way to get rich is to get into the government and that is the reason that men pay to get in," wrote the Dutch pamphleteer Claudius Civilis in 1747. ${ }^{11}$ At the pinnacles of patrimonial states, economic rewards (and risks) could indeed be enormous. ${ }^{12}$ In the Netherlands, the regent patriciate received fixed "rents" or intermittent windfalls from office, such as the sheriff's (schout) percentage of the fines he imposed, an income that could be quite extensive, especially in the eighteenth century.$^{13}$ Beyond serving as a direct source of resources, state offices and privileges were a vehicle for broad control over the conditions of making and keeping money, and over economic affairs generally. Dutch regents, for example, who invested over half their fortunes in state bonds in the eighteenth century, also used their positions in the state to decide the interest rates that their loans would command, and to block reforms in the fiscal system that seemed disadvantageous to them. ${ }^{14}$

Last but emphatically not least, there was a gendered, familial component to the pursuit of patrimonial privilege. Dutch regents were stirred by visions of their own ascendant lineages (geslachten): in that they were typical of early modern elite family heads, whether landed or mercantile, petty squires or rulers. ${ }^{15}$ Paulus Teding van Berkhout 
(1609-1672), a member of the Hague patriciate, characteristically reminded his children that they formed only "a link in a growing chain" of Van Berkhout generations, and that they should care for the wealth and possessions intended not only for their pleasure, but for the family's descendants (nageslacht) - those men whose name he bore, and who would bear his name in turn. ${ }^{16}$ Heritable privileges, including patrimonial offices and rentes, functioned as both lineage property and a kind of "property in politics" in many Old Regime societies, including the United Provinces. Corporate elites acquired pieces of the nascent state, in some cases selling them or passing them on to descendants. These properties came to resemble land, as relatively immobile family assets. ${ }^{17}$ When dependence on patrimonial privilege was essential to, and even the primary basis of, elite families' dominant position, conveying reliable access to privilege to the next generation became an urgent matter, synonymous with the social reproduction of the family itself.

Viewed from one family's pespective, there were several ways in which to do this, in which, that is, a family could ensure that its son and heir acceded to a position of privilege while conserving his status as a representative of the patriline. The family could buy an office or privilege. ${ }^{18}$ But the solution of venality was not always possible in a patrimonial political economy. Most high offices in the United Provinces could not legally be directly bought and sold, or formally inherited, although elites did buy lesser but lucrative state offices for their progeny, such as the venal postmasterships. More often, Dutch families followed a second path, that of nepotism. Family heads had prospective heirs appointed to non-venal offices, in many cases simply appointing them themselves. These offices lay at the outset of conventionally understood career paths, ending in a directorship of a privileged corporate body, such as the East Indies Company, a seat on the town council (vroedschap), or even access to its inner circle, the mayoralty (burgemeesterschap). If all went well, an heir would eventually either ascend into the regency, or (if his father were already a regent) replace him as the family head and its political representative. ${ }^{19}$ Of the first thirty-six Amsterdam vroedschap members in newly independent Holland (installed in 1578), only nine who had available descendants or relatives were not succeeded by them at their deaths, a pattern that characterized the Amsterdam patriciate down to the end of the early modern era. ${ }^{20}$ Furthermore, for much of this period, nepotism was seen as perfectly acceptable: the eighteenth-century diarist who commented uncritically that Mayor Bicker of Amsterdam had earmarked the sinecure 
of vendumeester van schepen en koopmanschappen, "worth 6000 guilders a year," for his fourteen-year-old son Henrik appears to have been typical. $^{21}$

Family heads who wanted to install or maintain their families in the sanctum of high office also had to practice the "politics of marriage" (huwelijkspolitiek): to marry well, and marry their children well. "Men frequently regarded marriage in terms of what it would do for their line," concludes one historian of the early modern Dutch landed gentry; the same was true of urban patriciates, in the United Provinces and elsewhere in Europe. ${ }^{22}$ Marriage gave a family normative claims on the allied family's patrimonial privileges and offices (which could, in the case of lesser offices, be directly acquired via dowries) and it created a web of political supporters. The "right" alliance also polished family prestige. ${ }^{23}$ Not surprisingly, elite families kept careful genealogical records - not only of their own pedigrees, but of other families with which they had intermarried, and sometimes of those with which intermarriage was considered plausible. The powerful Backer family, for example, researched or collected the genealogies of 320 other Amsterdam regent families, many of which were related by marriage to the Backer clan, as well as drawing up huge chronological lists of Amsterdam families that had boasted one or more burgomasters from 1343 to $1727{ }^{24}$ As far as these Dutch genealogists were concerned, other families were categorized and evaluated as good lineages and marital prospects in terms of the temporal depth and continuity of the representation of their male members in patrician offices and, if they were noble, landed estates.

The importance of marriage to elite and especially regent families was also evinced in the close management of children's marital prospects, culminating in complex and protracted negotiations between the family heads who were considering whether to consent to the alliance, ${ }^{25}$ and in wedding rituals so elaborate that town governments weighed sumptuary laws restricting the extravagance of the festivities. ${ }^{26}$ Dutch elite families did not generally arrange marriages for their sons and daughters, but they did exercise a significant amount of control. Parents and conventionally designated members of the kin group sponsored the social activities at which eligible candidates were scrutinized, and parents retained legal veto rights over their children's choice of spouse until 1809, after the collapse of the Dutch Old Regime, invoking them on the rare occasions when children flouted normative constraints. In those limit cases, families levelled negative sanctions against perceived misalliances, including disinheritance and social ostracism. ${ }^{27}$ 
From the perspective of the family, the two practices of marriage and inheritance were interdependent. If each wedding and inheritance settlement represents the playing of a card in the family's hand, to adopt Pierre Bourdieu's metaphor for a moment, each move in the "game" depends both on the hand that has been dealt, and the family's skill in playing it. ${ }^{28}$ The family's hand was played with an eye to a collective, intergenerational career path. It was conceived by the players as reaching fruition over several generations of politico-economic accumulation and alliances, and involving differing degrees of sacrifice from various family members who thought of themselves as joined in a common lineal fate. Two important methodological implications follow. First, the temporal horizons within which actors made decisions extended beyond any one individual's life expectancy, and the behavior of family heads will make sense only if we keep this in mind. Second, the members of the elite family acted with reference to the patriline and the group, and their actions must be situated accordingly. Yet to say that these families shared an idea of a common fate is certainly not to say that family members shared values stressing equality or that intrafamilial stresses and tensions were absent. Sacrifice for the lineage was unevenly distributed along the lines of gender and age, as was the capacity to reshape one's lot.

Consider the likely trajectories of the children of the regency. Higher offices were traditionally reserved for the eldest sons, even when a town charter did not limit the number of immediate family members that could sit on the town council, so younger sons were relegated to lesser positions, assuming the roles of supporter of and understudy to their older brothers. They could sometimes marry into other elite families, becoming the surrogate son and heir if that family lacked one. ${ }^{29}$ Others among them sought fame and fortune in the Indies, hoping to return to found a collateral branch of the family in another town. In very rare cases, younger brothers contested their subordinate position. ${ }^{30}$ The agency of daughters was even more sharply circumscribed. They could marry, or remain in the bosom of their family of origin. The regency was largely Protestant, so the cloister doors were closed to most of its women.

Bourdieu's card-game-theoretic analogy breaks down at this point, because it bypasses the role of power in the family, and the affectual, nonrational component of family practices. In a patriarchal patrilineal system, first of all, men are the key players. Daughters marry and are absorbed into families different from those into which they are born, 
and the generalized exchange of women helps guarantee trust among men. ${ }^{31}$ It functions as a medium by which the heads of the families concerned recognize past politico-economic alliances and commit themselves to present and future connections. In Amsterdam, the judicious gift of a daughter could buttress an old political faction, or shift a man into a new one, as when the prominent regent Corver married his daughter Maria Margaretha to his enemy Nicolaas Geelvinck as a peace offering. ${ }^{32}$ Second, the moves made by male family heads (and male and female surrogates acting in their places) are informed by historically specific forms of masculinity, by values and norms that emphasize the role of the male progenitor and the centrality of patrilineal selfhood. Messages about the value of the lineage and a man's place in it emphasized genealogies of office, rather than a strict aristocracy of blood..$^{33}$ The Bicker family archive in Amsterdam holds an emblematic document that testifies to the author Hendrik Bicker's pride in his patriline's past record and future prospects, as well as to the Bickers' long representation in city government offices and monopolies. Headed "Fourteen Generations Beginning with...", it spans a two-hundred-fifty year period from the 1400 s to the 1680 s, listing each Bicker male, his offices and privileges, the names of his wife or wives, his sons who also held positions, and culminating with Hendrik himself, at that time an Oud-Schepen, a member of the magistracy ${ }^{34}$ The document was to be passed down to Hendrik's sons, to be continued by future generations. The Bickers' is a particularly detailed example, but such records are not unusual. ${ }^{35}$ Along with the office genealogies came other items symbolizing the patriline's continuity: family portraits, the house, the largest portion of money. ${ }^{36}$ For men in the regency, their own patriarchal honor, patrilineal pride, and patrimonial privilege could not be parsed.

The family values of dominant men are of predominant interest here, because they mattered more than women's subcultures for high politics. The values held by dominant men were multivocal, but more straightforward than elite women's. Women faced conflicting calls on their allegiances when they left their natal lineages and joined others at marriage, ${ }^{37}$ and women's "virtue," understood in a cultural context of sexual purity and subordination, symbolized the honor and integrity of both the patrilines from which they sprang and those that they joined and perpetuated. ${ }^{38}$ Equally important, male family heads were able to act on their values, mortgaging their own and their family's futures for a dynastic vision, and trying to use the state to that end. But note that family heads were themselves systemically constrained. Father's and 
son's capacities to dispose of family property were legally circumscribed in favor of descendants, and the family sanctions directed at mesalliances included those contracted by the head of the family himself. ${ }^{39}$ The reproduction of the patrilineage was normatively governed, functioning as if the position of men took precedence over that of women, and that of the eldest over the youngest, with the first rule limiting the second. ${ }^{40}$ There were minor differences between the family practices of regents and landed elites in the Netherlands in this regard. Among the Dutch regent patriciate, great wealth and the relative mobility and divisibility of finance and merchant-capital stocks, major forms of regent assets, allowed daughters and younger sons to inherit part of the patrimony. Dutch women's property rights also varied regionally, and were in general better than those of English elite women.$^{41}$ Nevertheless, the eldest son (or his functional substitute) was preferred among both the landed gentry and the regent patriciates, whether in inheritance of the family demesnes, or in filling the offices identified with the family, respectively ${ }^{42}$

Although analysts have repeatedly registered the empirical presence of family and gender in politics, it is striking that theoretical analyses of patrimonial systems have failed to do justice to the gendered, familial component of the motivations of elites and rulers, or of the rules of reproduction of the system itself. ${ }^{43}$ These analyses have thus missed the range of social-structural and ideological outcomes that ensued. When the reproduction of a ruling elite rests on gendered family principles (including marriage, inheritance, and paternal authority), then familial patterns are also constitutive of societal modes of politico-economic reproduction. They determine how political alliances are formed and how power is transferred, how new members of the elite are recruited, and how political rule is legitimated. The next section deals with how these rules of reproduction came to characterize the patrimonial state itself.

\section{What is a familial state and how does it work?: The Dutch case}

As patriarchal family and lineal networks and ideologies were woven into the web of patrimonial power, they constituted a Dutch equivalent of what one might call a familial state. Let me clarify what I mean by that term. First, gendered familial criteria were constitutive of political authority. This era was still one, in Steven Ozment's memorable phrase, "when fathers ruled." 44 The regents grounded their political claims on the basis of hereditary qualification and patriarchal power, rather than 
on the basis of adherence to rational-legal procedure or other substantive standards of justice. ${ }^{45}$ Beginning with Willem I, hailed as Vader Vaderlands (Father of the Fatherland), the stadholders also invoked the legitimating ideologies of paternal authority and dynasty in attempts to claim or consolidate the sovereign authority they insisted accompanied that office. They also drew on these ideologies when seeking to extend their authority to new territorial or substantive domains. In this they were less successful than their continental royal counterparts, but not completely so. ${ }^{46}$

Second, the important political offices and privileges were distributed to men on the basis of their family ties and position. Sitting burgomasters allotted the higher city offices to family members, and lesser ones to their clients, as well as exercising jurisdiction over appointments to key positions at the provincial and Generality level, such as deputies to the States-General and Raad van State. ${ }^{47}$ Thus, family representation in the state extended both horizontally, such as in the town of Zutphen in 1747 , when six of the twelve city aldermen belonged to one extended family, and over time, such as in Hoorn, where the Breedhoff family held the principal magistracies and postmastership for three generations. ${ }^{48}$ Both tendencies were present in Amsterdam. ${ }^{49}$ The stadholders and their lieutenants also sought to build familial patronage networks with the offices and privileges under their jurisdiction, drawing on the noble dynasties of van Heeckeren, Bentinck, or the Schimmelpenninck van der Oye, for top posts in the military, church, and judicial hierarchies. ${ }^{50}$ Regents and stadholders composed and created dynastic officialdoms. ${ }^{51}$ In the case of the position of the stadholders themselves, who were traditionally from the House of Orange, the potency of family criteria in state recruitment is obvious.

States can be said to be in the making when properly political functions are anchored in a relatively centralized, differentiated organization that controls the principal concentrated means of coercion within a contiguous territory. ${ }^{52}$ The more developed the state, the more that political activities are organized in specific institutions, and the more that roles in the state sector are handed out according to a set of distinct, specialized requirements, rather than according to incumbents' roles in other institutions - including the family ${ }^{53}$ In patrimonial systems, both the relationship among state positions and the legitimation of the nascent state are in part familially defined. Thus, patrimonial systems should be conceptually distinguished from both rational-legal bureaucracies, and patronage systems, in which holders of offices are recruit- 


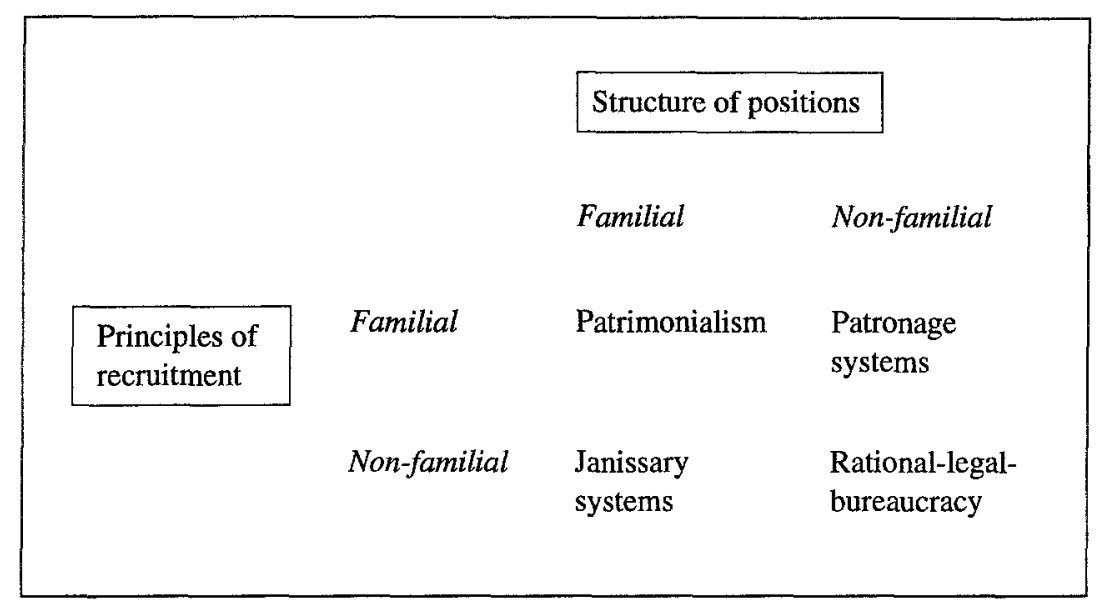

Fig. 1. Schematic typology of state structures.

ed largely according to particularistic - including familial - criteria but in which offices themselves are bureaucratically structured. They also differ from janissary-type systems, in which candidates for familiallydefined or household positions were routinely recruited by capture or adoption, and stamped with new identitites (see Figure 1).

In a patrimonial state, we would expect to find characteristically gendered, familial patterns of political conflict and alliance. Such was the case in the Dutch Republic. First, the stadholders and regents struggled over contending dynastic claims to rule. Orangist dynastic claims and the policies of international alliance and war that accompanied them persisted alongside, and in tension with, the power of the regent family regimes. Can we make sense of the history of the Dutch Republic, including its very survival as an independent state, without considering the charismatic and organizational role of the House of Orange in the war of independence against Spain? The impact of Willem III's marriage to his niece Mary Stuart and their ascension to the English throne as William and Mary at the Glorious Revolution? Willem IV's capacity to "play the English card" in his dealings with recalcitrant Amsterdam regents, by threatening English military intervention to force his reinstatement as hereditary stadholder with expanded executive powers? Surely not. Yet the stadholders never succeeded in becoming absolutist rulers, and not simply because the Dutch economy depended on trade, as is often asserted. The ebb and flow of their dynastic power cannot be understood without reference to the rhythms of family life. The capacity of the House of Orange to make claims to wider dynastic preroga- 
tives that promoted their power at home - including rights of succession to England's throne - was undermined by the history of posthumous male heirs and long minorities that marked the so-called "stadholderless eras" and favored the consolidation of estatist patrimonialism. ${ }^{54}$

The regents also fought among themselves. Recruitment of relatives could lead to flagrant violations of traditional limits on town councils inscribed in civic charters, as regents sought to include more of their male relatives. An outraged 1736 letter to the Holland Raad van State from Balthasar Huydecoper called attention to attempts by the Texel regents to do just that. ${ }^{55}$ Letters and legal cases decry alleged family take-overs of local East Indies Company boards. ${ }^{56}$ These sorts of practices evoked resistance from opposing, often newly-displaced, cliques, and were accompanied by multi-generational conflicts among families inside the state. In the Amsterdam vroedschap, the rivalry between the Bickers and the hard-nosed Calvinist colonial merchant Reynier Pauw and his sons' faction continued throughout the first half of the seventeenth century. "T7 "Two houses, both alike in dignity..." but even more in ambition. Regent family feuds were overdetermined by the stadholders' family claims and clienteles. Throughout the early modern era, power shifted back and forth between patriciate families sympathetic to the Orangist cause and those intent on minimizing the stadholders' influence. $^{58}$

When access to a city council seat became definitive of regent family position, family feuds in the patriciates became more heated, and the increasing stakes involved provoked an unmanageable level of competition among the corporate elite. This problem pervaded the urban regencies by the eighteenth century. In the Amsterdam vroedschap, family fault-lines crystallized in the famous Sautijn Scandal, when a clique led by burgomaster Jeronimus de Haze de Gregorio, nephew of the well-connected Joannes Hudde, and opposed to the ascendant Corver family, exposed the extortionate office sales of Willem Sautijn, the brother of burgomaster Nicolaas Sautijn (member of the Van Bambeeck family clan and staunch Corverite), and his associate burgomaster Jan Six, also a member of the ruling Corver faction. Sautijn and Six had sold offices for thousands of guilders and divided the proceeds between themselves. In 1717-1724, Sautijn had made a minimum of 22,820 fl. via office sales, including many in the East Indies Company. During the long and acrimonious trial (1724-1731), many prominent regents were found guilty of selling offices, including burgomaster Jan 
Trip; Pieter Six, schepen and later burgomaster; and Bonifacius Bisschop and Arend van der Burch, both members of the Admiralty Board. Nicolaas Sautijn even sold a gravedigger's office for 8,000 guilders in 1721, which may have been the cause of his not being elected burgomaster again after 1725. In an ironic twist, De Haze himself was found to have sold offices in 1723: among others, the office of East Indies Company boekhouder van de equipage for the tidy sum of the 16,000 guilders. ${ }^{59}$ These leading lights of the regency ended up in court not because their actions were unusual, but because heightened family conflict over leverage in the town council bared habitual but nominally illegal practices.

Dynastic struggles have long been thought to affect political cycles, but we know much less about their impact on politico-economic trajectories. ${ }^{60}$ The Dutch case offers an instructive and ironic exemplar of the unintended developments that can stem from the successful resolution of a collective action problem. The regents reacted with an array of settlements, or contracts of correspondence (contracten van correspondentie). These contracts formalized the distribution of city offices in written succession rules, which laid out systems by which all eligible elite families would take turns getting mayoralties, East Indies Company directorships, and other corporate privileges. The contracts regulated the membership in and control over corporate bodies, which were the conditions for capital accumulation, political power, and family honor. In the short run, they were a brilliant institutional solution: they protected specific families' stake in an offfice, and guaranteed that all regent families' office genealogies would continue unbroken. By regulating relations among dynasts, the contracten van correspondentie solved this early modern elite version of the classic "tragedy of the commons." ${ }^{161}$ Such contracts existed in Hoorn from the 1720 s, in Gouda from 1748, in Leiden from 1702-1721 and 1741 on, in Amsterdam from 1752 , and elsewhere. ${ }^{62}$

The contracts even addressed potential pitfalls, or threats to regent dominance. First, when successful dynasties hold power on a permanent basis, they tend to accumulate clients and are more likely to fall due to overspending on patronage. ${ }^{63}$ This was a real possibility in the Netherlands, where many high offices or privileges carried rights to dispense or sell other privileges, and where the States-General endorsed the traffic. ${ }^{64}$ The alternation among dynastic groups minimized this particular byproduct of the prerogative of successful dynasts to name non-familial clients to lower-level positions. Second, such a sys- 
tem enabled the regent dynasts to close ranks against outside pressures. It frustrated the stadholders' attempts to encroach further on regent prerogatives. ${ }^{65}$ These features, which were most likely unanticipated outcomes of the contracts, made the system even more stable. Regent families had successfully laid claim to political institutions, which became the de facto inheritable property of various lineages. Intentionally or not, the male representatives of these families had constituted a state that had the functional effect of reproducing their patrilineages. ${ }^{66}$

The formalization of family appropriation of state office reaffirmed family exclusivity in the regent patriciate. Regent circles became increasingly closer to new entrants, and a smaller circle of elites controlled offices more tightly. ${ }^{67}$ This closure was compounded by the falling birthrate of the regency in the eighteenth century, and produced demographic shortfalls of men from regent families deemed suitable for high office, and dramatic and persistent vacancies in the town councils. ${ }^{68}$ In some cases, such as in Hoorn and Leiden, the vacancies were filled via recruitment of burghers, who were married off to regent daughters. In Hoorn the demographic crisis spanned the entire decade of 1711-1721, and provoked the patriciate to replenish its ranks from the town's wealthy merchants by means of this method. In other cases, such as in Gouda, the regents sought to recruit new members from outside their city. ${ }^{69}$ Elsewhere, however, the regents simply recognized and accepted the shrinkage of the state body. They did not call for any broadening or relaxation of the gendered, familial criteria for admittance.

It would have been surprising if they had done so. Family structures and norms constrain these criteria, and these structures and norms are not infinitely malleable. The normative definitions of who is included in families and who may join or head them vary, but within institutionalized limits. The idiom of the "forbidden degrees" (verboden graden) of marriage, to give just one salient example, was both legally established and enforced by religious, civil, and community sanctions throughout western Europe.$^{70}$ Furthermore, it seems likely that the formalization of family/state links would have strengthened the position of the father in regent families, both by augmenting the resources he controlled, and by symbolically investing him with political authority, making it less likely that he would want to dilute or sacrifice his position. If further research upholds this hypothesis, it may also help explain why historians have failed to uncover systematic evidence of increased warmth and affect in regent families, in contrast to burgher or even more hum- 
ble families, over the course of the early modern period..$^{71}$ The identification of regent family head and state would have created powerful pressures countering the rise of a more egalitarian, companionate family among that fraction of the elite, and would have been likely to have imbued the family head with an even greater sense of his own patriarchal importance. ${ }^{72}$

The regents' embrace of politico-economic privilege and office was also associated with a turn away from merchant capitalism toward passive rentiership. ${ }^{73}$ The fortunes of Leiden regents are relatively typical in composition. From 1700 to 1780 , over 62 percent of their capital was invested in state bonds, and under 1 percent in trade or production. By contrast, Leiden merchants and manufacturers invested 22 percent of their capital in trade or production. ${ }^{74}$ The tilt toward rentier status was accompanied by the admission of fewer merchants into the town councils from the late seventeenth century. Of the twenty-four new mayors in Amsterdam during 1718-1748, for example, only two were active merchants. ${ }^{75}$ The percent of burgomasters and councillors with no recorded occupation (who are conventionally assumed to live off their rents), and who owned a country seat, also rose over time, although not monotonically. ${ }^{76}$ This trend extended to VOC directorships. Twenty-three (30 percent) of the Amsterdam directors between 1748 and 1794 were merchants or manufacturers, while 38 (49 percent) had no recorded occupation, and were thus almost certainly rentiers. At least 52 (68 percent) owned a country seat. Thus, although there were proportionately more merchants and manufacturers in the VOC directorship than in the Amsterdam town council at large, the figure had dropped dramatically from the 100 percent of the VOC's inaugural years. ${ }^{77}$ The shift from trade to finance capital, which offered a lower return on investment but higher prestige and economic security, was compatible with elite family heads' emphases on investing for their families with an eye to stabilizing the position of future generations.

\section{Decline and fall}

When corporate family cliques captured offices and privileges in estatist patrimonial political economies, the effect on state policy and the political economy hinged on who they were and what they wanted: whether they were merchant capitalists, feudal landlords, landed capitalist aristocrats, or a plurality of elites in conflict or coalition, whether 
they wanted to expand colonial trade or dreamed of continental territorial conquest. This is not to argue for an ahistorical instrumental theory of the state, but to recognize the triangle of patriarchal family, dominant class, and political privilege that characterized early modern patrimonial systems in general and the Dutch case in particular. So, in the Golden Age (Gouden Eeuw) of seventeenth-century Holland, the merchant-capitalist Bicker family controlled the apparatus at the Amsterdam mayors' disposal, including the Indies Companies. Without overmuch hyperbole, one could say that this was the point at which a single family came closest to ruling the world. Then Dutch dynastic officialdom favored the explosive development of mercantile capitalism on a world scale, advantaging Dutch elites and the Dutch population (but certainly not the peoples of Brazil, Africa, India, and Indonesia).

Yet the Dutch political economy declined in the eighteenth century. ${ }^{78}$ Trade suffered, not only in the bulk commerce in grain, herring, and salt, but also in manufactured and finished goods, such as textiles and colonial goods destined for reexport. Other countries were increasingly able to process and ship their own commodities, dealing directly with one another instead of via the Dutch middleman, and to enforce protectionist measures against the Netherlands. ${ }^{79}$ The East Indies Company's control in the Indies was the most enduring pillar of the entrepot system, but the VOC's politico-economic position deteriorated badly from mid-century ${ }^{80}$ Indigenous manufacture was even harder hit. ${ }^{81}$ This was a sturdy nail in the coffin of entrepot trade, for Dutch manufacture rested on foreign markets over which the Dutch were losing their grip, and the conventional outlets for its products were disappearing. This was true of England too, but there the blow was dulled by investment in home industry, and the subjugation of expanded colonial markets, just as the Netherlands' markets were eroding.

So what went awry for the Netherlands? The usual explanations of the decline (achteruitgang) attribute it to several politico-economic factors. Prominent among the external pressures cited are increased European economic competition and military inroads, especially into Dutch colonial territories. The domestic factors include a relative dearth of certain raw materials for industry, and comparatively high and rigid wages in urban areas. ${ }^{82}$ No doubt these factors should figure as parts of any complete explanation. Yet the above arguments also point beyond, to an understanding of how Dutch statemaking and the exercise of power intrinsic to sustaining a system of entrepot and colonial trade 
Belief of elite family head that family practices reproduce lineage



Time one

Reproduction of patrimonialism

Time two

Exogenous and endogenous

politico-economic factors
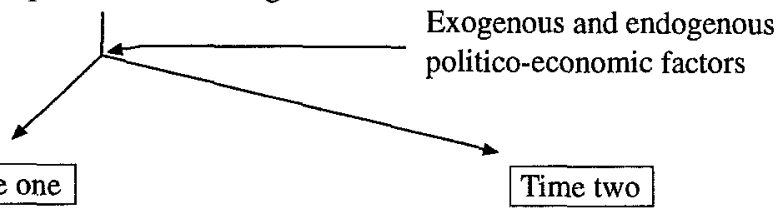

Decay of patrimonialism

Fig. 2. Schematic representation of central arguments.

were also undermined from within. The very family practices and gender ideologies that had sealed in the rise of the Netherlands made possible the accumulation and strengthening of patrimonial privilege and position that contributed to its decline. Figure 2 represents the argument in its starkest form, to clarify the following narrative.

How did the reproduction of lineages come to undermine the patrimonial political economy? The mechanism was an interactive one. As interfamily settlements, the contracts of correspondence reaffirmed and stabilized the localism of regent power structures. Taxes, naval policy, foreign and colonial policy remained subject to regent control, conducted via offices that the regents established, appointed, and filled, and state development took on a pronounced local cast. The over 3,000 offices in mid-eighteenth century Amsterdam alone contrasted with the comparatively low total of central state offices, about one to two hundred in the early seventeenth century and only three hundred in $1800 .^{83}$ The naval and colonial apparatuses, which formed the political basis of Dutch mercantile strength and of the impressive military force the Netherlands brought to bear on European and colonial foes, were similarly structured. The regents set up and headed the five overlapping admiralties, responsible for the collection of customs in their areas and for maintaining the navy (funded by customs proceeds), as well as the multiple constituent chambers of the chartered companies, which were the major shapers of early modern colonial policy. ${ }^{84}$ 
It is clear that the patriciate family regimes curtailed state support of domestic manufacture. The regencies consistently ignored manufacturers' criticism of existing guild regulations, continuing to protect traditional urban production and to create new guild structures beholden to them, and to maintain legislation against rural proto-industry ${ }^{85}$ The Amsterdam regents were also instrumental in blocking protective tarriffs for domestic manufacture in the 1720s and again in the 1750s; the regents supported low duties and "freer" transit trade. ${ }^{86}$ What is more surprising is how the system came to undermine trade itself, the lifeblood of the Netherlands. The localism of the Dutch political economy had not been a significant disadvantage at the outset of the early modern period. Other European countries faced similar situations, ${ }^{87}$ and the Dutch towns and their hinterlands were both relatively extensive and cohesive, and largely controlled by merchant capitalist families, rather than by landed feudal dynasties or unstable elite coalitions ${ }^{88}$ By the latter part of the era, however, when the Dutch were no longer operating from an advantaged position in the world political economy, and regent families had become exclusive, entrenched rentiers, this structure had become a poor framework from which to respond to the rising tensions occasioned by the decline of Dutch trade and the rise of British commerce and manufacturing.

The system was messy and expensive. Contemporaries agreed that the overlapping naval and colonial organization was cumbersome, and deplored the inflated expense due to its administrative costs. ${ }^{89}$ More important, the organization disposed each enclave to respond individually to politico-economic pressures. Each admiralty cut customs rates, and collaborated with merchants in evading them, hoping to compete with its counterparts. ${ }^{90}$ This Hobbesian scramble contributed to a drop in revenues, and to an insecure and inadequate supply of funds for the navy. ${ }^{91}$ The chartered company directorates, merged with the regent elites, were subject to analogous dynamics, and proved equally impervious to reform from within and vulnerable to challenges from without. ${ }^{92}$

Certainly some of the regents and the stadholders were aware of the country's politico-economic problems, and considered ways to address them. Naval buildup would have required that enforcement mechanisms be introduced for corporate bodies that lagged in their payments or refused to pay, and eventually that those intermediary bodies be eliminated altogether. Revamping the structure of colonial policy would have required changing the terms of the pact on which the Dutch 
state was founded: its allotment of ultimate sovereignty to local and provincial corporate bodies, and the system of representation by which the regents constituted the policy-making members. The "enlightened" reformer Simon van Slingelandt, secretary to the Council of State and later Grand Pensionary (1727-1736), proposed the most thoroughgoing set of reforms along these lines: that the grip of the regencies on offices be loosened, and that rights to policy-making, taxation, and adjudication of urban and provincial differences be vested in neutral third parties (i.e., central state officials). Slingelandt's proposal was taken up by the Grote Vergadering of 1717, the second constitutional convention in the history of the United Provinces, but no changes could be agreed upon, and none was adopted. ${ }^{93}$ Later suggestions for reform, although less precisely articulated, followed much the same pattern, and were also blocked.

The regents' collective inertia in the face of these problems may seem puzzling. After all, they had collectively created the contracts of correspondence, so why couldn't (or wouldn't) they reform the state, one source of the Netherlands' politico-economic decline that seems to have been under their control? To reform the state, however, the regent family heads would have had to do away with its familial structure. Yet their money was secured in it. Their authority, status, and very identity were tied to the state, in part because it would also be their sons' and sons' sons'. Instead, elite families embraced their piece of the polity more tightly, just as the legitimating political symbolism of heredity, birth, and blood began to conflict with the newer Enlightenment and popular attitudes of merit, utility, and reason pervading eighteenthcentury Europe, including the Netherlands. ${ }^{94}$

The formalization of the proprietary claims of regent families to state offices and privilege evoked struggles for change that gathered steam in local movements across the Netherlands in 1747-1748. For the first time, organized pressures against the regents emerged from the burgher strata "just below." Reform movements in the northern provinces sought to eliminate venality; ${ }^{95}$ those in Holland and the south, such as that of Rotterdam, demanded that office sales be opened to a wider public, with proceeds going not to the regents, but to a truly public purse. ${ }^{96}$ Although an analysis of the scope of the Patriot Revolution (1782-1787) lies beyond the scope of this argument, it is striking to note that the small merchants and manufacturers who sparked the sequence of municipal revolts challenged the position of both the urban patriciates and the Prince of Orange. They rallied the disaffected 
with familially-loaded charges of "nepotism," regent dynastic decay, and criticism of family government and the contracts of correspondence. Some strands of the movement criticized pretensions to patriarchal authority, and celebrated the virtues of fraternal government and popular, or at least burgher, sovereignty. ${ }^{97}$

The regents and stadholder joined together to resist. They opposed democratic municipal elections and the elimination of their patrimonial prerogatives, and violently suppressed the "Dutch Spring" (Lente) in a counterrevolution paid for by a loan of 90,000 pounds by the English state, and carried out by Prussian mercenaries. The conflicted and debilitated state fell to the French invasion of 1795 and was dismantled following a radical Patriot (French-sponsored) coup d'etat in $1798 .{ }^{98}$ The local family regimes, suppressed by the revolution, were reinstated after the French occupation was over, and endured in some towns, such as Amsterdam, until definitively broken by the constitutional revolution of $1848 .{ }^{99}$

\section{Conclusions and issues for further exploration}

My argument that gendered family practices imparted specific dynamics to Dutch societal development is a resolutely open one, calling for comparative study. It prompts us to ask questions of other European patrimonial elites, whose lineage honor, capacities to accumulate economic resources, and abilities to exercise power derived from their membership in and control over corporate bodies. To what extent were they recruited into and did they exercise control over corporate bodies due to their statuses as current or prospective male family heads, as was the case with the Dutch regents and stadholders? Did the lack of differentiation between elite families and state privileges structure politico-economic development in similar ways? When and under what conditions did the specific European articulation of powerful patrilineages, bilateral kinship, barriers against endogamy, and strongly marked ideologies of gender difference encourage familial solutions to state vulnerability, such as replacing one ruling lineage with another, widening the definition of lineal eligibility, or vesting power temporarily in a female relative of the ruling family who would govern as a surrogate for a male heir? When, alternatively, did this articulation create space for new, non-familial solutions? These questions suggest a restructuring of research agendas into the relations between the dynastic dynamics of patrimonial rulers and elites, and the consequences of those dynamics for state formation and policy. 
The argument also opens toward non-European cases. In Old Regime China, for example, filiality was also a route to state power, and family principles and idioms were major factors structuring the articulation among the state's component parts. (It is not surprising that the critique of patriarchy and nepotism was a key feature of Chinese oppositional politics, just as it was in the Netherlands.) ${ }^{100}$ The familial state concept is an ideal type, an analytical tool that stresses certain characteristics in order to isolate common social-structural tendencies in a broad array of empirical situations. ${ }^{101}$ Depending on the prevailing family form, however, the type concept can and should be made more precise. Nuclear (and stem) family forms predominated among the elite in northwest Europe, including the early modern Netherlands, while extended (and joint) families were common in many contemporary Eastern countries. The extended family structure characteristic of China, which was associated with joint households, put a premium on fraternal solidarity and evinced "a particularly authoritarian form of pariarchy," as well as a prominent political role for the mother-in-law, "patriarchy's female deputy in the Chinese family." 102 To the extent that these and other specific family features were embedded in the state, I would expect them to foster distinctive forms of macro-political tension, alliance, and change. ${ }^{103}$

This is not to say, of course, that gendered family practices were the sole causes of any historical outcome in the West or East. They were but one strand, albeit an important and analytically neglected one, that interacted with the rise of the capitalist mode of production in various ways. Wherever forms of politically-constituted property (or privatelyor corporately-owned forms of power) remained in the hands of patrimonial elites, the intra-elite squabbling characteristic of patrimonialism was increasingly accompanied by new emergent tensions. The old patrimonial elites still depended on corporate bodies as key mechanisms in securing, maintaining, and extending status, power, and wealth, but new and independent economic agents were not anchored in these bodies, and they called loudly for new forms of political power divested of such "archaic" mutual obligations. ${ }^{104}$ This widening dichotomy was a feature of most early modern European countries; it was even present in countries like the Dutch Republic, where wage labor, rather than coercive exploitation of a peasantry, was the dominant type of surplus extraction.

At this critical juncture, which arose in Europe at various times, the familial character of nascent states would be likely to block social- 
structural development in two ways. The first hypothesized mechanism stems from the interests or desires of the occupants of state positions and holders of patrimonial privilege. They had an interest in maintaining their positions, and could be expected to resist substantial change in social arrangements when it involved loosening their grip on the state. Even when elites faced obsolescence, they would be likely to refuse to restructure or surrender their privileges. We can expect the actors in question, the male heads of elite families, to insist on this point, because they had more then their own, or even their families', or their class' economic benefit in view. ${ }^{105}$ They were also emotionally attached to patriarchal patrimonial family authority. The family head's ideological identification with the honor of the lineage was central to his selfrepresentation. ${ }^{106}$ It engendered impulses that we "moderns" now think of as contradictory and mutually exclusive, such as the desire to support his children economically and emotionally, and to deploy them as pawns in family strategies, but those impulses were not contradictory in early modern Europe. ${ }^{107}$ There ties between parents and children, as well as between husbands and wives, were structurally multivocal, because they were embedded in the patrimonial package of family, dominant class and state, and embodied in genealogies of office..$^{108}$ These genealogies were at once means of family survival, bids for power, and glorious narratives of clan honor. It is to be expected that elites would fight hard to defend them.

The second hypothesized mechanism issues from the capacities, or rather incapacities, that familial states created. The repertoire of roles in such states was strictly limited, as were the incumbents and the acceptable idioms of rule. We can thus expect familial state policies to be relatively inflexible with respect to capital accumulation and taxation, particularly from the perspective of rising merchant and manufacturing capitalists who were not tied to traditional corporate bodies. Furthermore, when family heads staked out local or provincial bodies as their own turfs, their implantation would be likely to raise structural barriers to policy formation and state-building on a national level.

The differentiated development of a political structure does not necessarily make it functional or even viable. States can be unmade as well, along the same dimensions, including familial ones. In the Dutch case, as we have seen, the growing urgency of the demands placed on the patrimonial state by foreign economic competition and military threat encouraged endogenous devolutionary tendencies. Economic resources, power, and legitimacy flowed to particularistic regent familial 
regimes at the expense of the overall politico-economic structure in which those local regimes were embedded, however insecurely. The extent of coordination among key state elements - the multiple family regimes, urban and provincial governments, the regents and the stadholder - declined, and processes of politico-economic disintegration set in, rendering the Dutch state more vulnerable and undermining its adaptability to external pressures. ${ }^{109} \mathrm{Had}$ politico-economic privileges and offices not functioned as the patrimony of elite families, I have argued (counterfactually), reformers would have been more capable of introducing measures to address politico-economic pressures at home and abroad, before the epochal revolutionary upheavals of the $1780 \mathrm{~s}$ presented another, more drastic, solution.

Under some circumstances, the barriers imposed by elite familial goals and the structure of state capacities they helped sustain could be surmounted. These obstacles were overcome in England during the seventeenth century. Elite families began to relinquish patrimonial privilege then, and the flight from privilege helped stabilize political power there in the following century. To what extent were innovative family practices a source of the English elite's notorious longevity, the comparative stability of the organization of political power and evolutionary changes in state government? We do not know. But one implication of my argument here, if it is correct, is that the variability in the central trajectories of patrimonial societies, whether development or devolution, can be explained in part by variations in gendered family practices, and we should look to those practices for one answer to the English question.

\section{Acknowledgments}

A previous draft of this article was presented at the Workshop in Comparative Politics and Historical Sociology at the University of Chicago, and at the Center for the Study of Social Transformations (CSST) and the Family Studies Seminar, both at the University of Michigan. I would like to thank the participants in those gatherings, as well as Ron Aminzade, Nancy Curtin, Els van Eyck van Heslinga, Femme Gaastra, Marjolein 't Hart, Judy Howard, Edgar Kiser, Barbara Laslett, Gian Poggi, Lawrence Stone, and Theory and Society's Editors for their helpful comments and suggestions. The article draws on some of the research I have conducted in the Netherlands, which was funded by the Social Science Research Council and by the American Council of Learned Societies. 


\section{Notes}

1. In this article, the terms "United Provinces," "Dutch Republic,"and "the Netherlands" all refer to the seven northern provinces and their contiguous dependent territory. "Holland" designates the largest of the seven provinces, and "Dutch" the people and the language. The "Low Countries" refer to the territory of the present-day Netherlands and Belgium.

2. Regents (regenten) are conventionally defined as occupants of high state offices, notably the councils (vroedschappen) of the over fifty voting towns in the early modern Netherlands. In practice, they are a subset of the "elite," which also includes members of the landed gentry and merchant and industrial capitalists who do not hold office.

3. For the classic discussion of patrimonialism, in which the following paragraph is partly based, see Max Weber, Economy and Society (Berkeley/Los Angeles: University of California Press, 1968 [1922]), especially 226, 293-297, 1006-1007, $1010-1013,1022-1023,1028-1031$. Other terms currently in vogue for this type of states include neo-feudal, predatory, absolutist, brokerage, tax/office, tributary, fiscal/military, and agrarian bureaucratic.

4. Patrimonial privilege and the reproduction of the patrimonial polity itself are rooted in "traditional values," which, as Mark Gould puts it, "necessitate a legitimation of innovation in terms of past practice." See Gould, Revolution in the Development of Capitalism: The Coming of the English Revolution (Berkeley/Los Angeles: University of California Press, 1987), 168. In such polities, notes Gianfranco Poggi, corporate bodies were "constrained chiefly by the concurrent, traditional rights vested in other individuals and bodies" (The State, Its Nature, Development and Prospects, Stanford: Stanford University Press, 1990, 48-49). Yes, although neither Gould's nor Poggi's otherwise excellent books recognizes that these bodies were shaped and honeycombed by family cliques, and that the "traditional" rights and values on which they were based were patriarchal and familial. I discuss this issue further below.

5. On the Habsburg period, the most useful English-language source is James Tracy's Holland under Habsburg Rule, 1506-1566 (Berkeley/Los Angeles: University of California Press, 1990). (Given the likely audience for this article I cite English-language references whenever possible.) Subsequent quasi-monarchical protectors, chosen on the basis of Dutch alliances with France and England, were ousted after they tried to bend Dutch foreign policy to the dictates of the French and English crowns (I. Schoffer, "De Opstand in de Nederlanden, 1566-1702," in I. Schoffer et al., editors, De Lage Landen van 1500 tot 1780, Den Haag: Agon, 1988, 146-152). After independence, each provincial State appointed a stadholder (generally but not by legal necessity the same individual until 1747). The provincial States were in turn composed of deputies, largely regent delegates of the voting towns.

6. See Tom Burns ("Sovereignty, interests and bureaucracy in the modern state," in British Journal of Sociology 31, 1980, 491-506) on patrimonial rulers' consolidation of authority by means of creating new corporate bodies, or reviving traditional ones.

7. "The customary way the history of the Dutch Republic is told, which makes the government of States-with-stadholder the normal pattern and the two stadholderless periods ... interruptions that distort the pattern," notes Herbert Rowen in The Princes of Orange: The Stadholders in the Dutch Republic (New York: Cambridge 
University Press, 1988, 110-111) "may be as false as the opposite vision of the followers of De Witt in his own time and in subsequent generations who saw the Republic in its purity as government without a stadholder." See also pages 95-130 and 148-162.

8. See Weber's "rule by honoriatores (notables)" (Economy and Society, Berkeley/ Los Angeles: University of California Press, 1968 [1922], 1009-1010; 10381042). "Estatism" is preferable, in my view, because it makes explicit the conceptual parallelism to absolutism. For an English-language summary of the complex system of Dutch government, see Bernard Vlekke's Evolution of the Dutch Nation (New York: Roy Publishers, 1945).

9. J. de Witte van Citters reviews instances of the ubiquitous pursuit of privilege in eighteenth-century Europe. See his edited Contracten van correspondentie en andere bijdragen tot de geschiedenis van het ambtsbejag in de Republiek der Vereenigde Nederlanden ('s-Gravenhage: Martinus Nijhoff, 1875, v-xxxii).

10. Amsterdam Gemeente Archief 292: \#1739.

11. Cited in J. J. de Jong, Met goed fatsoen: De elite in een Hollandse stad: Gouda 1700-1780 (Amsterdam: Dieren, 1985, 38).

12. Witness Richelieu's "fruits of office," the largest fortune accumulated in France until that time, or the dramatic trajectories of Essex, the Cecils, and many Tudor and Stuart grandees. For the sources of Richelieu's fortune, see Joseph Bergin's Cardinal Richelieu: Power and the Pursuit of Wealth (New Haven: Yale University Press, 1985). On the English grandees, see Lawrence Stone's The Crisis of the Aristocracy 1558-1641 (Oxford: Clarendon, 1965, 398-504) and his Family and Fortune: Studies in Aristocratic Finance in the Sixteenth and Seventeenth Centuries (Oxford: Clarendon, 1973). Paul Bamford's Privilege and Profit: A Business Family in Eighteenth-Century France (Philadelphia: University of Pennsylvania Press, 1988) usefully disaggregates three major types of privilege that underpinned ancien regime French business fortunes: seigneurial domain, venal office, and state monopoly.

13. For the schout, see O. Vries ("Geschapen tot een ieders nut. Een verkennend onderzoek naar de Noordnederlandse ambtenaar in de tijd van het Ancien Regime," Tijdschrift voor Geschiedenis 90, 1977, 330) and J. G. Smit ("De ambtenaren van de centrale overheidsorganen der Republiek in het begin van de zeventiende eeuw." Tijdschrift voor Geschiedenis 90, 1977, 388-390).

14. The best English-language source on how the Dutch patricians structured the terms of their own loans to the state is James C. Riley, International Government Finance and the Amsterdam Capital Market, 1740-1815 (New York: Cambridge University Press, 1980, 68-82).

15. The lineage is the diachronic face of kinship: a patrilineage is said to descend from a "founding father," and to persist in the form of a single line (when each generation has one male child), or in branches (when there are several male children). See Andrejs Plakans's Kinship in the Past: An Anthropology of European Family Life 1500-1900 (Oxford: Blackwell, 1984, 213).

16. Quoted in C. Schmidt ("Een lengteprofiel van het Hollandse patriciaat: Het geslacht Teding van Berkhout 1500-1950," in J. Albers and M. Prak, editors, De bloem der natie: Adel en patriciaat in de noordelijke Nederlanden, Amsterdam: Boom 1987, 133). Lawrence Stone and Jeanne C. Fawtier Stone offer a witty discussion of indirect heirs and name-changing among the English landed elite: "a fiction that was a necessity if the ideal of family continuity was to be realized in practice." (An Open Elite? England 1540-1880, New York: Oxford University Press, 1986 [1984]: 91). 
17. For a general discussion of how this process functioned, see Ralph E. Giesey, "Rules of inheritance and strategies of mobility in prerevolutionary France," The American Historical Review 82 (1977): 271-289.

18. In early modern France, after the paulette of 1604 , even high offices were bought and conveyed by deed of inheritance. See Roland Mousnier, La Venalité des Offices sous Henri IV et Louis XIII (Rouen: Editons Mangard, 1971 [1945]).

19. This career pattern resembles those identified for other patrimonial elites. See, for example, Y. Moreau on the Liège patricians ("Les bourgmestres de Liège au XVIII siècle. Provenance et biographie sociale d'une aristocratie à la fin de l'Ancien Régime," Standen en Landen LXXIV, Kortrijk-Heule, UGA, 1978), Robert Forster (Merchants, Landlords, Magistrates: The Depont Family in EighteenthCentury France, Baltimore: Johns Hopkins University Press, 1980) and Ralph Giesey ("Rules of inheritance and strategies of mobility in prerevolutionary France," The American Historical Review 82, 1977) on the ancien régime French bourgeoisie.

20. See Johan E. Elias, De vroedschap van Amsterdam (Amsterdam: Israel, 1903-1905), xlii, Table VII.

21. The diarist is quoted in L. Van Nierop, "Het dagboek van Jacob Bicker Raye 1732-1772: Van stedelijke ambtenaren" (Jaarboek van het Genootschap Amstelodamum 36, 1939, 213-251), 220. Positive normative expectations extended beyond the nuclear family to the wider kin network, and cut both ways. Hence Jacob van Citters, mayor of Middelburg, regularly answered letters from officeseekers stamped with his own family tree, indicating the relationship of the petitioner to the mayor up to the sixth degree. (G. Coumans, "Geld en geluk: De familie Van der Muelen in gezinshistorisch perspectief 1600-1800", in Jaarboek Oud-Utrecht (1984), 99-120), 103.

22. The quotation is from Sherrin Marshall, The Dutch Gentry 1500-1650: Family, Faith and Fortune (New York: Greenwood Press, 1987), 51. See also the articles collected in Aalbers and Prak, De bloem der natie.

23. For specific case studies that attest to the multiple functions of marriage for regent families, see among others, De Jong (Met goed fatsoen) on Gouda; L. Kooijmans (Onder regenten: de elite in een Hollandse stad, Hoorn 1700-1780, Amsterdam: De Bataafsche Leeuw, 1985) on Hoorn; P. W. De Lange ("De ontwikkeling van een oligarchische regeringsvorm in een Westfriese stad: Medemblik 1289-1699," Hollandse Studien 3, 1972, 119-157) on Medemblik; Porta (1975) on Amsterdam; M. Prak (Gezeten burgers: De elite in een Hollandse stad, Leiden 1700-1780, Amsterdam: Dieren, 1985) on Leiden. The pioneering work on a familieregering ("familial regime"), one that rested on the sons-in-law of the family head, was Th. Jorissen's edition of the Memorien van mr. Diderik van Bleyswijk, burgemeester van Gorinchem 1734-1755 (Utrecht: Kemink \& Zoon, 1887).

24. Amsterdam Gemeente Archief PA172: \#40-45, 104.

25. These negotiations gave rise to detailed contingency planning and regulative documents. For the Amsterdam patriciate, see the documents collected in Amsterdam Gemeente Archief 195, \#60, \#61, \#66, \#73, \#79.

26. "In 1655, when Dr. Tulp and Burgemeester Bontemantel succeeded in pushing through Amsterdam's law against extravagant wedding feasts, the measure was enacted against a background of an appalling visitation of the plague and a serious trade depression brought on by defeats and blockades in the naval war against England. Even then, the law was less draconian than might have been the case, limiting celebrations to fifty guests and a duration of two days!" (Simon Schama, 
The Embarrassment of Riches: an Interpretation of Dutch Culture in the Golden Age, New York: Alfred A. Knopf, 1987), 186.

27. See Marshall (The Dutch Gentry, 37), Schama (The Embarrassment of Riches, 441-445), and Kooijmans (Onder regenten, 122-125), among others. The point can be illustrated by another example from the rich history of the Bicker clan. In 1650, the Amsterdam burgomaster Andries Bicker, who had refused his consent to the proposed marriage of his 26-year-old son Gerard to Alida Koninks on the grounds that the Koninks's social status was too far below the Bickers', brought a case against his defiant son before the magistrates of the Hoge Raad, who decided in the father's favor. Gerard and Alida finally married in 1656, after both Bicker parents were dead and after Gerard had asked the Raad, "in loco lineagensis," to reverse its decision, and been successful. See J. Th. Smidt and Heleen C. Gall, "Recht en gezin," in G. A. Kooy, editor, Gezins Geschiedenis: Vier eeuwen gezin in Nederland(Assen/Maastricht, Van Gorcum), 37-39.

28. See Pierre Bourdieu, The Logic of Practice (Stanford: Stanford University Press, 1990 [1980]), 148.

29. See Murk Van der Bijl's study of the town of Middelburg: Idee en Interest: Voorgeschiedenis, verloop en achtergronden van de politieke twisten in Zeeland en vooral in Middelburg tussen 1702 en 1715 (Groningen, Wolters-Noordhoff, 1981). It would be interesting to know whether the marriages and migrations of younger sons to other towns or provinces solidified wider geographic bonds among elites. The question, unanswerable at the moment, has obvious implications for nationbuilding.

30. In the Gevers family of eighteenth-century Rotterdam, one younger brother, who had temporarily filled the vroedschap seat of his bankrupt older sibling - a ne'erdo-well gambler and family disgrace - tried to hang onto the seat when the latter returned from the East Indies. Dr. Els van Eyck van Heslinga is researching the Gevers case (for the legal documents, see Algemeen Rijksarchief Den Haag 2.21.070).

31. Claude Levi-Strauss originally coined the term. See his The Elementary Structures of Kinship (Boston, Beacon Press, 1949). Note that there was an endemic tension between "marrying out," which broadened family ties, and "marrying in," which could enhance family wealth and cohesion. In rich Dutch families, cousin marriage was not uncommon (e.g., Kooijmans Onder regenten, 125).

32. She was a rich prize: well-dowered and seventeen years younger than Geelvinck, who was a widower with five children. See Antonio Porta, Joan en Gerrit Corver: De politieke macht van Amsterdam (1702-1748) (Assen: Van Gorcum, 1975), 157-158. In the Netherlands, women were still given in marriage, but they were not completely given away - especially not when the bride was of a higher class than the groom. C. Schmidt shows that when the heads of regent families were in financial straits, their daughters were more frequently married off to wealthy but lower-status merchants. If deemed necessary by the regent family, the new son-inlaw could occupy a subaltern office by virtue of his marriage, and his son in turn could take his place among the regency. See Schmidt's dissertation, Om de eer van de familie: Het geslacht Teding van Berkhout 1500-1950; een sociologische benadering, (Amsterdam: De Bataafsche Leeuw, 1986).

33. In western European elites, these messages were reinforced by religious edicts, including culturally sanctioned associations between families and model Biblical patrilines. See, in general, Joel T. Rosenthal, Patriarchy and Families of Privilege in Fifteenth-Century England (Philadelphia: University of Pennsylvania Press, 1991), 
chapter one. Simon Schama deals with the Dutch elite's deep sense of religious election, touching on the correspondence between popular visions of the Prince of Orange and biblical paternal associations, but the point should be extended more widely. See chapter two of The Embarrassment of Riches. The seventeenth-century regent Paulus Teding van Berkhout's written advice to his children illustrates that sense of election, as applied to a particular family. See Cornelis Schmidt, Om de Eer van de Familie, 56-64.

34. Amsterdam Gemeente Archief 195: \#36.

35. Later additions extend the line to 1772 . Another especially rich example, drawn up by B. Huydecoper, lists the chronology of high offices filled by generations of Huydecoper men in Amsterdam from 1578 to 1749 (Algemeen Rijksarchief Utrecht 67: \#4). Regarding gentry genealogies, see Marshall (The Dutch Gentry), $2-3$.

36. See among others Prak (Gezeten burgers, 196-197). Regarding the significance of family archives and treasured objects for intra-family meaning systems from the early modern period up through the nineteenth century, see Henk Nicolai, "De genealogie van het voorwerp: Dierbare voorwerpen en familiecultuur bij de Kingma's te Makkum," in Peter te Boekhorst, Peter Burke, and Willem Frijhoff, editors, Cultuur en maatschappij in Nederland 1500-1850 (Heerlen: Open Universiteit, 1992), 285-318. The analysis does not take explicit account of gender, but the symbolic role of the stamvader (family founding father) is especially clear.

37. Historians are beginning to explore how women's understandings of family and lineage differ from dominant male institutionalized interpretations. Margery Wolf's "Beyond the patrilineal self: Constructing gender in China" (unpublished manuscript) deals centrally with this issue. Marshall argues that Dutch gentry women may have identified with their families of origin, their husbands' lineages, and their new "core families," those children to which they had given birth, and their children's children (The Dutch Gentry), 50-51.

38. Lotte van de Pol discusses sexuality in the early modern Netherlands in "Seksualiteit tussen middeleeuwen en moderne tijd," in H. Peeters, L. Dresen-Coenders, and T. Brandenbarg, editors, Vijf eeuwen gezinsleven. Liefde, huwelijk en opvoeding in Nederland (Nijmegen: SUN, 1988), 163-193. Chapter six of Schama (The Embarrassment of Riches) also deals with Dutch views of women's sexuality.

39. See especially L.J. van Appeldoorn, Geschiedenis van het Nederlandsche huwelijksrecht voor de invoering van de Fransche wetgeving (Amsterdam: Uitgeversmaatschppij Holland, 1925); Donald Haks, Huwelijk en gezin in Holland in de 17de en 18de eeuw: Processtukken en moralisten over aspecten van het laat 17de-en 18de-eeuwse gezinsleven (Assen: Van Gorcum, 1982); Marshall, The Dutch Gentry. Primogeniture, entail, and their functional substitutes have thus seemed to some commentators to undermine paternal authority, but if the locus of family honor and paternal authority is understood to reside not in the individual or the nuclear family but in the lineage, necessitating that "the lineage should enjoy a wealth, dignity, and authority commensurate to its inherited status and right" (Mervyn James, Family, Lineage, and Civil Society: A Study of Society, Politics, and Mentality in the Durham Region, 1500-1640, Oxford: Clarendon, 1974, 184), it is not surprising that the strengthening of entail tends to be accompanied by stronger patrilineal prerogatives. See J. P. Cooper, "Patterns of inheritance and settlement by great landowners from the fifteenth to the eighteenth centuries," in J. Goody, J. Thirsk, and E. P. Thompson, editors, Family and Inheritance: Rural Society in Wes- 
tern Europe 1200-1800 (Cambridge: Cambridge University Press, 1976).

40. See chapter two of A. R. Radcliffe-Brown, Structure and Function in Primitive Society (New York: Free Press, 1952).

41. A. S. de Blecourt, Kort begrip van het oud-vaderlands burgerlijk recht (Groningen: J. B. Wolters, 1950), 72-88; Alice Clare Carter, "Marriage counselling in the early seventeenth century: England and the Netherlands compared," in J. van Dorsten, editor, Ten Studies in Anglo-Dutch Relations (Oxford University Press, 1974), 94-127.

42. The legal mechanisms of primogeniture and entail had spread throughout Europe, in response to pressure by landed elites who wanted to keep their estates together for family posterity, although the rules were not as stringently enforced in the Netherlands as in some other European countries. On primogeniture, see Frances Gies and Joseph Gies, Marriage and Family in the Middle Ages (New York: Harper, 1987).

43. In the canonical theoretical texts of early modern European state formation, the roles of family, household, and lineage are empirically important, but do not figure in the theory of the system. One striking example, despite its title, is Perry Anderson's Lineages of the Absolutist State (London: New Left Books, 1974).

44. See Ozment's When Fathers Ruled: Family Life in Reformation Europe (Cambridge: Harvard University Press, 1983).

45. Historians have argued that patriarchal concepts or ideologies of family and gender can provide a medium by which politics were conducted and contested in early modern Europe. See among others, Gordon J. Schochet, Patriarchalism in Political Thought (Oxford: Blackwell, 1975). Schochet's discussion of the mobilization of patriarchal doctrine as a defense of Stuart absolutism has been revised and "gendered" by Carol Pateman, in chapter four of The Sexual Contract (Stanford: Stanford University Press, 1988). See also Simon Schama, Citizens: A Chronicle of the French Revolution (New York: Knopf, 1989), and Lynn Hunt, The Family Romance of the French Revolution (Berkeley/Los Angeles: University of California Press, 1992), and Harriet B. Applewhite and Darline G. Levy's edited collection, Women and Politics in the Age of the Democratic Revolution (Ann Arbor: University of Michigan Press, 1990), which deals with a number of early modern European countries.

46. See J. J. Poelhekke, Frederik Hendrik, Prins van Oranje: Een Biografisch Drieluik (Zutphen, 1978), 151-153, and Rowen's The Princes of Orange, 137.

47. See Johan E. Elias, Geschiedenis van het Amsterdamsche Regentenpatriciaat (Den Haag: Martinus Nijhoff, 1923), 201-202; and Vries, "Geschapen tot een ieders nut," 338-340.

48. These examples are culled from Simon Schama, Patriots and Liberators: Revolution in the Netherlands 1780-1813 (New York: Vintage, 1977), 50-52. Amsterdam burgomasters had more offices to dispense (over 3,200 in the mid-eighteenth century) than other towns did, but their general procedure otherwise typified that of burgomasters elsewhere. For Amsterdam, see T. Bussemaker, "Lijst van Ambten en Officien ter Begeving Staande van Burgemeesteren van Amsterdam in 1749," Bijdragen en Mededeelingen van het Historisch Genootschap 28, 1907, 474-518.

49. Between 1698 and 1748 only forty regents held the nine annually rotating senior offices of the city, and those regents were mainly members of the Corver clan. Joan Corver had assumed the leading position in the town council after the death of stadholder Willem III in 1702 , at the outset of the second stadholderless 
period, and the number of his family members holding the office of major rose quickly: in 1707, of the nine sitting mayors, five belonged to the Corver family. (Elias, Geschiedenis, 195). The Corvers intermarried with the Van Bambeeck, Hooft, Munter, and Van den Bempden families over the next thirty years, and the ramifying bloc held power until 1747-1748 (Elias, De uroedschap, cxxxix, Tab. 3-5; Porta, Joan en Gerrit Corver).

50. See Schama (Patriots and Liberators, 76-77); and chapter three of Marshall, The Dutch Gentry. Regarding the stadholders' creation of patronage, see A. J. C. M. Gabriels, De heren als dienaren en de dienaar als heer: het stadhouderlijk stelsel in de tweede helft van de 18de eeuw (1989, Ph.D. dissertation, University of Amsterdam), 145-168, 202-222, 330, 361.

51. The historian Raph Giesey used this term to describe the situation in France ("Rules of inheritance," 282). See also Sarah Hanley, "Engendering the state: Family formation and statebuilding in early modern France," French Historical Studies 16 \# 1 (Spring 1989): 4-27, which focusses on the familial-juridical discourses of the state elite.

52. Charles Tilly provides a helpful discussion of the dimensions of state development, although his text does not take family or gender into account as structural principles in politics. See his Coercion, Capital and European States, AD 900-1990 (Cambridge: Blackwell, 1990).

53. See S. N. Eisenstadt, The Political System of Empires (New York: Free Press, 1963); and Talcott Parsons, Societies: Comparative and Evolutionary Perspectives (Englewood Cliffs: NJ, Prentice-Hall, 1966), 21-25.

54 C. A. Tamse's edited collection, Nassau en Oranje in de Nederlandse Geschiedenis (Alphen aan den Rijn, A. W. Sijthoff, 1979) includes useful articles on each of the stadholders. The relevant English-language summary is Rowen, The Princes of Orange.

55. Huydecoper accused the regents of appointing excess magistrates in order to incorporate their family members, and he pointed out in no uncertain terms that they were violating the town's 1509 charter. For the relevant documents, see Algemeen Rijksarchief Utrecht $67, \# 377$.

56. Algemeen Rijksarchief Den Haag 1.04.02 \#4659 contains several of these fruitless legal cases and the corresponding dispensations.

57. For the rivalry between the Bickers and Pauws, see Elias, Geschiedenis.

58. This pervasive trend is most carefully documented for Middelburg, in Zeeland, by Van der Bijl in Idee en Interest.

59. The records of the Sautijn scandal are collected in Amsterdam Gemeente Archief \# 5061, 641A.

60. Ibn Khaldun, who wrote in the fourteenth century, discusses the impact of dynastic struggles on some aspects of politics. See his El Muggadimah (Princeton: Princeton University Press), 133-142.

61. See Garrett Hardin's “The tragedy of the Commons" (1968), collected in Garrett Hardin and John Baden, Managing the Commons (San Francisco: W. H. Freeman and Company, 1977).

62. For Amsterdam, see Amsterdam Gemeente Archief \#5059, 93; for Hoorn, see Kooijmans, Onder regenten; for Gouda, De Jong, Met goed fatsoen; for Leiden, Prak (Gezeten burgers, 264). In Enkhuizen, in 1730, a typical agreement noted the desire of the regents "not to exclude any of the gentlemen-councillors from the directing of affairs" (cited in Kooijmans, Onder regenten, 211). At times this system was less effective in suppressing factionalism, such as in Haarlem. See J. A. F. 
de Jongste, Onrust aan het Spaarne: Haarlem in de jaren 1747-1751 (Amsterdam 1984), 177-181.

63. See among others Jeremy Boissevain, Friends of Friends: Networks, Manipulators, and Coalitions (Oxford: Blackwell, 1974).

64. For office venality, see K. W. Swart, The Sale of Offices in the Seventeenth Century (The Hague: Martinus Nijhoff, 1949). The States-General had tried to deal with the perceived expansion of office sales with a 1715 plakaat against "taking forbidden gifts" and "corruption in the government" (Groot Placaet-Boeck 1638-1796 v, s'Gravenhage, 684). When the directive proved unenforceable, the States capitulated, imposing special taxes (ambtgelden) on office-holders upon assumption of offices, in essence taking a cut of venal transactions.

65. The stadholders had the oppoortunity to make inroads into the composition of town councils during national crises occasioned by attempted invasions (in 1672 and 1747). At those times, the quasi-monarchical component of patrimonial governance came to the fore. In 1748, Willem IV responded to the pleas of some Amsterdam merchants that their town government respond more readily to their concerns by appointing several active merchants to the council. Twelve of the seventeen new members came from mercantile families that had never sat in the council. See H. van Dijk and D. J. Roorda, "Sociale mobiliteit onder regenten van de Republiek," (Tijdschrift voor geschiedenis 84, 1971, 306-328, 326). Yet the Amsterdam regency was able to compel the stadholder to reach an accommodation with them before his early death in 1752 , and to set the bounds within which Willem $\mathrm{V}$ operated as well.

66. Some Amsterdam families were unusually successful in the quest for the wealth, power, and prestige that accompanied family privilege and continuity. Ideally, we would be able to specify quantitatively the practices associated with the preservation of some patrilineages and the extinction of others. Although I am engaged in some analysis along these lines, nothing will be definitive until the five meters of documents pertaining to Amsterdam regent appointments to state offices (1493-1813) are sifted. Thanks to Dr. Dudok van Heel for introducing me to these documents, available in the Amsterdam Gemeente Archief (\#5013), and for dissuading me from doing anything about them.

67. Van Dijk and Roorda, "Sociale mobiliteit."

68. Prak (Gezeten burgers, 189-190) discusses several explanations for the rising percentage of regents who were childless in the eighteenth century. He rejects existing explanations for demographic decline, and calls for further investigation. In his Revolution and Rebellion in the Early Modern World (Berkeley/Los Angeles: University of California Press, 1991), 110-123, 228-232, Jack A. Goldstone examines the consequences of demographic expansion, arguing that the improvement in the survival rate of younger sons was a factor in state political crises in England and France. Here again we would benefit from further research embedding demographic trends within their gendered and familial, as well as societal, context.

69. See Kooijmans (Onder regenten, 86-91) for Hoorn, and Prak (Gezeten burgers, 191) on Leiden. For Gouda, see De Jong (Met goed fatsoen).

70. For the early modern Netherlands, see Appeldoorn, Geschiedenis, especially 161. See also chapter two of Michel Foucault, The History of Sexuality 1 (New York: Vintage, 1980 [1978]), on the roles of canonical, Christian, and civil law, and custom, in governing marital relations, a domain "saturated with presciptions" that were "centered on legitimate alliance" (37-38). 
71. For an English-language discussion of maternal affection and domesticated fatherhood in burgher families, see chapter seven of Schama's The Embarrassment of Riches. Two useful summary overviews of the parent/child relationship in early modern Dutch families are Lily E. Clerkx, "Kinderen in het gezin," in G. A. Kooy, editor, Gezins Geschiedenis: Vier eeuwen gezin in Nederland (Assen/Maastricht: Van Gorcum, 1985) and Jan Noordman and Henk van Setten, "De ontwikkeling van de ouder/kind-verhouding in het gezin," in H. Peeters, L. Dresen-Coenders, and T. Brandenbarg, Vijf Eeuwen Gezinsleven: Liefde, huwelijk en opvoeding in Nederland(Nijmegen: SUN, 1988).

72. On the rise of the egalitarian family among the elite in early modern England, see Lawrence Stone, The Family, Sex and Marriage in England 1500-1800 (New York: Harper and Row, 1977), and Randolph Trumbach, The Rise of the Egalitarian Family: Aristocratic Kinship and Domestic Relations in Eighteenth-Century England (New York: Academic Press, 1978). In his introductory chapter, Rosenthal (Patriarchy) reviews some counterarguments.

73. This position was first argued convincingly by D. J. Roorda. See his "The ruling classes in Holland in the seventeenth century," in J. S. Bromley and E. H. Kossmann, editors, Britain and the Netherlands 2 (The Hague: Martinus Nijhoff, 1964). See also Peter Burke, Venice and Amsterdam: A Study of Seventeenthcentury Elites (London: Temple Smith, 1974).

74. Prak, Gezeten burgers, 117.

75. Elias, De vroedschap, 238.

76. There was a partial rollback of the percentage of rentiers and owners of country seats in 1672-1702 and 1748-1795, due to stadholders' interventions into the composition of the town council during national crises occasioned by attempted invasions (in 1672 and 1747).

77. The figures are from the data gathered in my dissertation, One's Company, Three's a Crowd: Merchant Companies and State-building in the Early Modern Netherlands, France and England, 1600-1800 (University of Wisconsin, 1990). The same shift characterized other chambers. Family ties continued to be the primary mechanism of transmitting control: in Rotterdam, for example, 66 percent of the directors stood in relation of son, father, or grandfather to one another. Twenty-six directors were succeeded by a son, son-in-law, or grandson. See Mathilde Kors, "De Bewindhebbers van de Kamer Rotterdam," in Historisch Museum Rotterdam Bulletin 2 (1988, 12-28): 16 .

78. Historians are still debating the character and timing of the Dutch decline. Four major positions have been put forward: (1) the economy stagnated from 1700 to 1780, after which it downturned sharply (Johan de Vries, De economische achteruitgang der Republiek in de achttiende eeuw, Leiden: Stenfert Kroese, 1959); (2) it declined absolutely from 1670 to 1750 , and then recovered slightly (Jan de Vries, "The decline and rise of the Dutch economy, 1675-1900," in G. Saxonhouse and G. Wright, editors, Technique, Spirit and Form in the Making of Modern Economies, Greenwich: JAI Press, 1984); (3) it continued to grow from 1695 into the nineteenth century (James C. Riley, "The Dutch economy after 1650: Decline or growth?" The Joumal of European Economic History 13, 1984, 521-569); (4) it declined after 1720 , precipitously after 1740 , and did not recover during the early modern era (J. G. van Dillen, Van rijkdom en regenten, s'-Gravenhage: Martinus Nijhoff, 1970; Jonathan Israel, Dutch Primacy in World Trade 1585-1740, New York: Oxford, 1989). For reasons not given here, but discussed at length in Adams (One's Company), I concur with the dates of decline given by Van Dillen and Israel, but emphasize the role of different explanatory factors. 
79. For the bulk and rich trades, see chapters seven and nine of Israel, Dutch Primacy.

80. For the best brief account of the VOC, see Fenme Gaastra, De geschiedenis van de VOC (Haarlem: Fibula van Dishoeck, 1982).

81. If there is room for some disagreement about the absolute versus relative decline of some sectors of trade, there can be less about the absolute regression of indigenous manufacture. For the textile industries, see Max Barkhausen, "Government control and free enterprise in Western Germany and the Low Countries in eighteenth century," in Peter Earle, editor, Essays in European Economic History (Oxford: Clarendon, 1974 [1958]), 245-246. A. M. van der Woude discusses the paper and canvas industries in Het Noorderkwartier (Wageningen: Veenman, 1972), 490-492 and 476-477. For tobacco processing, see Israel, Dutch Primacy, 388. Other industries that declined or disappeared were Zeeland's salt-refining, Delftware, and even the old mainstay, ship-building.

82. For a variety of explanations of the Dutch decline, see the references provided in footnote 76 above. Two caveats are in order, however. First, to evaluate the claim that the dependence on wind and peat, rather than the coal and iron that was used in eighteenth-century England and Sweden, made a difference in the Netherlands' failure to industrialize, we would have to have better data than are currently available on the relative costs of importing raw materials such as coal. Second, wages in urban areas may have been a problem, but this argument does not explain the lack of investment in the latter half of the eighteenth century, when real wages dropped dramatically.

83. See Marjolein 't Hart's The Making of a Bourgeois State: War, Politics and Finance During the Dutch Revolt (New York: Manchester University Press, 1993).

84. In the Amsterdam chamber of the VOC, at least 82 percent of the 77 men who served as directors at some time between 1748 and 1794 were burgomasters, magistrates, or served in some other capacity on the vroedschap. See Adams, One's Company.

85. See Swart, The Sale of Offices, 45; and N. W. Posthumus, Geschiedenis van de Leidsche Lakenindustrie, 3 vols. ('s-Gravenhage: Martinus Nijhoff, 1908-1939).

86. The final and most explicit debate on this subject before the sustained domestic and foreign challenges that brought down the Old Regime centered around the Proposition for a Limited Porto Franco, introduced before the States General and Holland States in 1751 by Willem IV. The proposal embraced a plan for strengthening and integrating the state as well as the entrepot trade. As such it appeared in conjunction with a scheme for the first national Council of Commerce, which could have paralleled the English Board of Trade, founded in 1696. See J. Hovy, Het voorstel van 1751 tot instelling van een beperkt vrijhavenstelsel in de Republiek (Groningen: J. B. Wolters, 1966), 238-365. Even in much-modified form, the proposal did not pass (ibid., 364ff.).

87. Kenneth Andrews, Trade, Plunder and Settlement: Maritime Enterprise and the Genesis of the British Empire: 1480-1630 (Cambridge: Cambridge University Press, 1984); Martine Acerra and Jean Meyer, La grande epoque de la marine a voile (Editions Ouest-France, 1987).

88. Jonathan Israel makes these two latter points forcefully in Dutch Primacy.

89. 't Hart, The Making of a Bourgeois State; Jacob Johan Steur, Herstel of ondergang: de voorstellen tot redres van de Verenigde Oost-Indische Compagnie, 1740-1795 (Utrecht: HES, 1984).

90. The customs were bringing in an average of 1.5 million guilders a year in the early eighteenth century, less than the seventeenth-century average of 1.7 million, 
according to J. M. F. Fritschy, De patriotten en de financien van de Bataafse Republiek (Den Haag: De Bataafse Leeuw, 1988), 35. Estimates of evasions of the customs range from 30-40 percent in Amsterdam and Rotterdam to almost 80 percent in Zeeland (Joh. de Vries, "De ontduiking der convooien en licenten in de Republiek tijdens de $18 \mathrm{e}$ eeuw;" Tijdschrift voor Geschiedenis 71, 1958; J. C. Westermann, "Statistische gegevens over den handel van Amsterdam in de zeventiende eeuw," Tijdschrift voor Geschiedenis 61, 1948, 3-15). The rate of evasion appears to have risen as well (Joh. de Vries, ibid., 225-226).

91. The English navy doubled its tonnage from 1714 to 1760 , deploying up to 10,000 men in peacetime and over 100,000 at the time of the American War. See John Brewer, The Sinews of Power: War, Money and the English State, 1688-1783 (New York: Knopf, 1989), 33, but the Dutch navy was increasingly undermanned and underequipped, unskilled, and technologically outdistanced. For the Dutch navy, see J. C. de Jonge, Geschiedenis van het Nederlandsche Zeewezen 4 (Haarlem: A. C. Kruseman, 1858-1862), 1-440.

92. Steur's Herstel of ondergang deals with reform efforts within the VOC.

93. See G. J. Schutte, "De Republiek der Verenigde Nederlanden, 1701-1780," in I. Schoffer, H. van der Wee, and J. A. Bornewasser, editors, De Lage Landen van 1500 tot 1780 (Den Haag: Agon, 1988), 276-279; and A. J. Veenendaal, "De Republiek voor laatst als grote mogenheid, 1702-1727," in Algemene Geschiedenis van Nederlanden 9 (Haarlem, Fibula-Van Dishoeck, 1980), 28. Van Slingelandt's analysis is recorded in "Aanwyfing van de waare oorfaaken van het jeegenwoordig groot verval in de generale Regeering van den Staat der Vereenigde Nederlanden, en van de noodige middelen van redres," Staatkundigegeschriften 2 (Amsterdam, Patrus Schouten), 1-90.

94. For the Dutch Enlightenment, see the essays on that topic in Margaret C. Jacob and Wijnand W. Mijnhardt's edited collection, The Dutch Republic in the Eighteenth Century: Decline, Enlightenment, and Revolution (Ithaca: Cornell University Press, 1992).

95. Swart, The Sale of Offices, 77-78.

96. Groot Placaet-Boeck $1638-1796$ vii: $106-108,828-829$.

97. Regarding the accusations of nepotism, see R. R. Palmer, The Age of the Democratic Revolution 1 (Princeton: Princeton University Press, 1959-1964), 364370. Nicolaas van Sas discusses the condemnation of the contracts of correspondence and familial government, particularly in the Patriots' two-volume political handbook, the Grondwettige herstelling van Nederlands staatswezen (Constitutional Restoration of the Netherlands' Political System, published 1784-1786). See "The Patriot Revolution: New perspectives," in The Dutch Republic in the Eighteenth Century, 91-120. See also chapter three of Schama, Patriots and Liberators. For a discussion of the role of women (rather than gender) in the Dutch upheavals, see Wayne te Brake, Rudolf Dekker, and Lotte C. van de Pol, "Women and political culture in the Dutch revolutions," in Women and Politics, 109-146.

98. For complementary English-language surveys of the entire period, see I. Leonard Leeb, The Ideological Origins of the Batavian Revolution: History and politics in the Dutch Republic 1747-1800 (The Hague: Martinus Nijhoff, 1973); and Schama, Patriots and Liberators.

99. For a complementary argument, see C. H. E. de Wit's De strijd tussen aristocratie en democratie in Nederland, 1780-1848 (Heerlen: Winants, 1965), which argues strongly, but on different grounds than this article, that there was continuity from the Patriots of the 1780 s to the liberals of 1848 . 
100. Maurice Freedman's Chinese Lineage and Society: Fukien and Kwangtung (New York: Humanities Press, 1966) discusses the structural relationship between the mandarinate and local lineage politics. See also Judith Stacey's Patriarchy and Socialist Revolution in China (Berkeley/Los Angeles: University of California Press, 1982), especially $68-79$, the section on elite family crisis. Note, however, that Freedman misleadingly poses the relationship of mandarinate and local family powers as one between "state" and "people," and Stacey does not explicitly discuss the state as a familial structure.

101. See chapter one of Weber, Economy and Society.

102. See Stacey, Patriarchy and Socialist Revolution, 53-54.

103. It should be clear that these remarks are meant to be suggestive of connections, rather than definitive in any way.

104. With respect to England, see Robert Brenner's Merchants and Revolution: Commercial Change, Political Conflict, and London's Overseas Traders, 1550-1653 (Princeton: Princeton University Press, 1993).

105. If we assume that regent family practices reduce to neo-utilitarian strategies, we run the risk of putting the causal cart before the horse. This also holds true when the concept of neo-utilitarian strategy is given a Marxian twist, and introduced under the guise of "class interest." In The Origins of the Family, Private Property and the State (New York: Pathfinder Press, 1972 [1884]), Frederick Engels argues that the nuclear family, and associated systems of inheritance, came about and persists because it serves the function of reproducing private property, and thus the dominant class. This may be an effect of the nuclear family, but there is no evidence that it was or is a cause. Even within the terms of the theory, Engels cannot explain one key step: why fathers should want to pass on their property to their "own" (biological) sons - anybody's sons could serve the economic purpose. This nonrational preference remains exogenous to, and inexplicable within, Marxism as it is currently understood.

106. The social-psychological mechanisms of identification with "the line" have been addressed at various levels of theoretical ambition and historical specificity. In The Politics of Reproduction (Boston: Routledge and Kegan Paul, 1981), feminist theorist Mary O'Brien hypothesizes a primal paternal reproductive anxiety, a desire for control over "the seed," as the cause of attempts by men to control women's reproduction. We are better served by a less grandiose, more historicized focus. For example, Elizabeth Wirth Marvick uses a court doctor's journal to clarify one striking aspect of the socialization of French kings, the extraordinary emphasis on the phallus communicated in a society that emphasizes male procreativity as integral to state power. See chapter three of Marvick, Louis XIII: The Making of a King (New Haven: Yale University Press, 1986).

107. Because both these components are in play, it is as important to avoid anachronistic romanticization of elite-family life as it is to avoid one-dimensional rationalchoice accounts. Certainly some fathers and husbands did love their children, and their wives, and wanted to secure their futures, as E. P. Thompson has written, "to try to throw forward some grid which will support them" ("The grid of inheritance: A comment," in Family and Inheritance, 346). Yet (pace Thompson) the metaphor of the grid is aptly double-edged; grids also restrict and entrap. As we have seen above, the boundaries of the normative structures that patterned family social position are as always most evident when transgressed. Parents were prepared to punish or disown children who threatened family honor and position, and the high courts to back them up. Neither the romantic nor the rational-choice 
perspective problematizes gendered power relations within the family or enables us to deal with the traces of such relations in politics.

108. On the structural multivocality of another elite, that of medieval Florence, see John Padgett and Christopher K. Ansell, "Robust action and the rise of the Medici, 1400-1434," American Journal of Sociology 98/6 (May 1993): 1259-1319. My point here has not been to explain the genesis of this belief system, which merits an article in itself, but to begin to draw out its explanatory possibilities.

109. "Disintegration" is a decline in the extent of coordination among a set of social units. See Charles Tilly, "Clio and Minerva," in J. C. McKinney and E. A. Tiryakin, editors, Theoretical Sociology: Perspectives and Developments (New York: Appelton-Century-Crofts, 1970) 451-452. 